\title{
Indole is an inter-species biofilm signal mediated by SdiA Jintae Lee ${ }^{1}$, Arul Jayaraman ${ }^{1}$ and Thomas K Wood $* 1,2,3$
}

Address: ${ }^{1}$ Artie McFerrin Department of Chemical Engineering, Texas A \& M University, College Station, TX 77843-3122, USA, ${ }^{2}$ Department of Biology, Texas A \& M University, College Station, TX 77843-3258, USA and ${ }^{3}$ Zachry Department of Civil Engineering, Texas A \& M University, College Station, TX 77843-3136, USA

Email: Jintae Lee - Jintae.Lee@chemail.tamu.edu; Arul Jayaraman - arul.jayaraman@chemail.tamu.edu;

Thomas K Wood* - Thomas.Wood@chemail.tamu.edu

* Corresponding author

Published: 18 May 2007

BMC Microbiology 2007, 7:42 doi:10.1186/147I-2180-7-42
Received: 26 October 2006

Accepted: 18 May 2007

This article is available from: http://www.biomedcentral.com/I47I-2/80/7/42

(C) 2007 Lee et al; licensee BioMed Central Ltd.

This is an Open Access article distributed under the terms of the Creative Commons Attribution License (http://creativecommons.org/licenses/by/2.0), which permits unrestricted use, distribution, and reproduction in any medium, provided the original work is properly cited.

\begin{abstract}
Background: As a stationary phase signal, indole is secreted in large quantities into rich medium by Escherichia coli and has been shown to control several genes (e.g., astD, tnaB, gabT), multi-drug exporters, and the pathogenicity island of $E$. coli; however, its impact on biofilm formation has not been well-studied.
\end{abstract}

Results: Through a series of global transcriptome analyses, confocal microscopy, isogenic mutants, and dual-species biofilms, we show here that indole is a non-toxic signal that controls $E$. coli biofilms by repressing motility, inducing the sensor of the quorum sensing signal autoinducer-I (SdiA), and influencing acid resistance (e.g., hdeABD, gadABCEX). Isogenic mutants showed these associated proteins are directly related to biofilm formation (e.g., the sdiA mutation increased biofilm formation 50 -fold), and SdiA-mediated transcription was shown to be influenced by indole. The reduction in motility due to indole addition results in the biofilm architecture changing from scattered towers to flat colonies. Additionally, there are 12-fold more $E$. coli cells in dual-species biofilms grown in the presence of Pseudomonas cells engineered to express toluene 0 monooxygenase (TOM, which converts indole to an insoluble indigoid) than in biofilms with pseudomonads that do not express TOM due to a 22 -fold reduction in extracellular indole. Also, indole stimulates biofilm formation in pseudomonads. Further evidence that the indole effects are mediated by SdiA and homoserine lactone quorum sensing is that the addition of $\mathrm{N}$-butyryl-, $\mathrm{N}$ hexanoyl-, and $\mathrm{N}$-octanoyl-L-homoserine lactones repress $E$. coli biofilm formation in the wild-type strain but not with the sdiA mutant.

Conclusion: Indole is an interspecies signal that decreases $E$. coli biofilms through SdiA and increases those of pseudomonads. Indole may be manipulated to control biofilm formation by oxygenases of bacteria that do not synthesize it in a dual-species biofilm. Furthermore, $E$. coli changes its biofilm in response to signals it cannot synthesize (homoserine lactones), and pseudomonads respond to signals they do not synthesize (indole). 


\section{Background}

It has been established that cell-to-cell signaling plays a role in the formation of some biofilms. For example, cell signaling controls the production and secretion of exopolysaccharides for Vibrio cholerae biofilms [1]. This signaling may be complex as $V$. harveyi uses three cell-sensing signals including $\mathrm{N}$-(3-hydroxybutanoyl) homoserine lactone (autoinducer-1, AI-1), furanosyl borate diester (AI2 ), and a signal, synthesized by CqsA, whose structure is unknown [2]. In addition, the quorum sensing signal $N$ (3-oxododecanoyl)- $L$-homoserine lactone controls biofilm formation in Pseudomonas aeruginosa [3], and we have found that in vitro synthesized AI-2 stimulates directly Escherichia coli biofilm formation $[4,5]$.

Indole is an extracellular signal in $E$. coli as it has been shown to regulate expression of astD, tnaB, and gabT in the stationary phase for planktonic cells [6]. Indole has also been shown to control multi-drug exporters in E. coli [7] as well as to regulate the pathogenicity island of pathogenic E. coli [8] (note tryptophanase activity has also been linked to killing of nematodes by $E$. coli but indole is not directly responsible for this effect [8]). Recently, indole has been shown to link plasmid multimerization and cell division [9]. Using DNA microarrays, we discovered that genes for the synthesis of indole (tnaAL) were induced by a stationary phase signal [10] and that the gene encoding tryptophanase, tnaA, was repressed 13 -fold in 6-day-old E. coli biofilms in complex medium [11]. These results implied that indole plays a role in biofilm formation since biofilm cells most closely resemble stationary-phase cells $[12,13]$. Using two E. coli mutants $y l i H$ and $y c e P$, we found that indole probably inhibits biofilm formation since these two mutations lead to biofilms with lower intracellular indole concentrations which leads to dramatic increases in biofilm formation and since the addition of extracellular indole reduced biofilm formation for these mutants [14]. In contrast, others have reported that indole induces biofilm formation in E. coli as the tnaA deletion decreased biofilm formation and the addition of indole restored it [15]. Hence, we sought here to explore this contradiction using DNA microarrays so that we could study the whole genome as well as use isogenic mutants to test our hypotheses. This approach has led to both the discovery and elucidation of the role of the biofilm regulators MqsR [4], BssR/BssS [14], Hha/YbaJ [16], and TqsA [5].

The physiological role of SdiA has been unclear in E. coli [17]. SdiA is a LuxR homologue that is a quorum-sensingregulated transcription factor in E. coli [18]; in other bacteria, LuxR systems control density-dependent gene regulation through homoserine lactones but $E$. coli does not have a homoserine lactone synthase [19]. In E. coli O157:H7, SdiA has been shown to regulate virulence fac- tors [20], and SdiA has been shown (by overexpressing SdiA from a plasmid) [21] to inhibit chemotaxis and motility genes in E. coli K-12, to repress tnaA, as well as to induce indole export via AcrEF [6]. Recently, it has been determined that SdiA responds to three different homoserine lactone signals $[19,22]$, and that SdiA controls acid resistance via a synthetic homoserine lactone [23].

To investigate the role of indole in biofilms, the isogenic mutations tnaA (encoding tryptophanase), $\operatorname{trpE}$ (encoding anthranilate synthase component I), tnaC (encoding the tryptophanase leader peptide), and trpL (encoding Trp operon leader peptide) were used since they control indole synthesis in E. coli [24] (Fig. 1). It was found here that homoserine lactone quorum sensing is related to $E$. coli biofilms via SdiA, and that indole is an inter-species biofilm signal that may be manipulated by other bacteria. In addition, the regulation of biofilms via indole is linked to acid resistance via known paths (e.g., hdeABD, gadAB$C E X)$. It was also found that homoserine lactone signals repress E. coli biofilm formation.

\section{Results}

The goals of this research were to determine whether indole influences E. coli and Pseudomonas sp. biofilm formation (using crystal violet staining for rapid results and flow cells to examine biofilm architecture) and to determine the genetic basis of this influence through DNA microarrays and isogenic mutants. The concentration of indole used here $(\sim 500 \mu \mathrm{M})$ was not toxic to E. coli since the growth rate at $500 \mu \mathrm{M}$ was reduced only by $7.6 \%$.

\section{Tryptophan mutations and indole concentrations}

The trpE, tnaC, and tnaA mutations in the tryptophan pathway (Fig. 1) reduced by a factor of 10 the intracellular indole concentration for E. coli K-12 in Luria-Bertani medium (LB) (Fig. 2). The trpL strain had 30\% more intracellular indole compared to the wild-type strain (Fig. 2) since $\operatorname{trpL}$ encodes the attenuator (Fig. 1). In addition, extracellular indole concentrations were reduced for the trpe, tnaC, and tnaA mutations (Fig. 2, $450 \mu \mathrm{M}$ reduced to 5 to $90 \mu \mathrm{M})$.

\section{Biofilm formation}

Since we have measured extracellular indole concentrations greater than $600 \mu \mathrm{M}$ with wild-type K12 [14], we added $500 \mu \mathrm{M}$ indole to E. coli $\mathrm{K}-12$ in LB supplemented with $0.2 \%(\mathrm{w} / \mathrm{v})$ glucose (LB glu) and found it decreases biofilm formation in flow cells (Fig. 3). LB glu was chosen since it reduces background indole concentrations (due to catabolite repression of tnaA [25]) so that exogenous indole would have a greater effect. The addition of indole to the wild-type E. coli changed the biofilm architecture from scattered towers to flatter colonies (Fig. 3A/3B). COMSTAT analysis (Table 1) indicated biomass was 


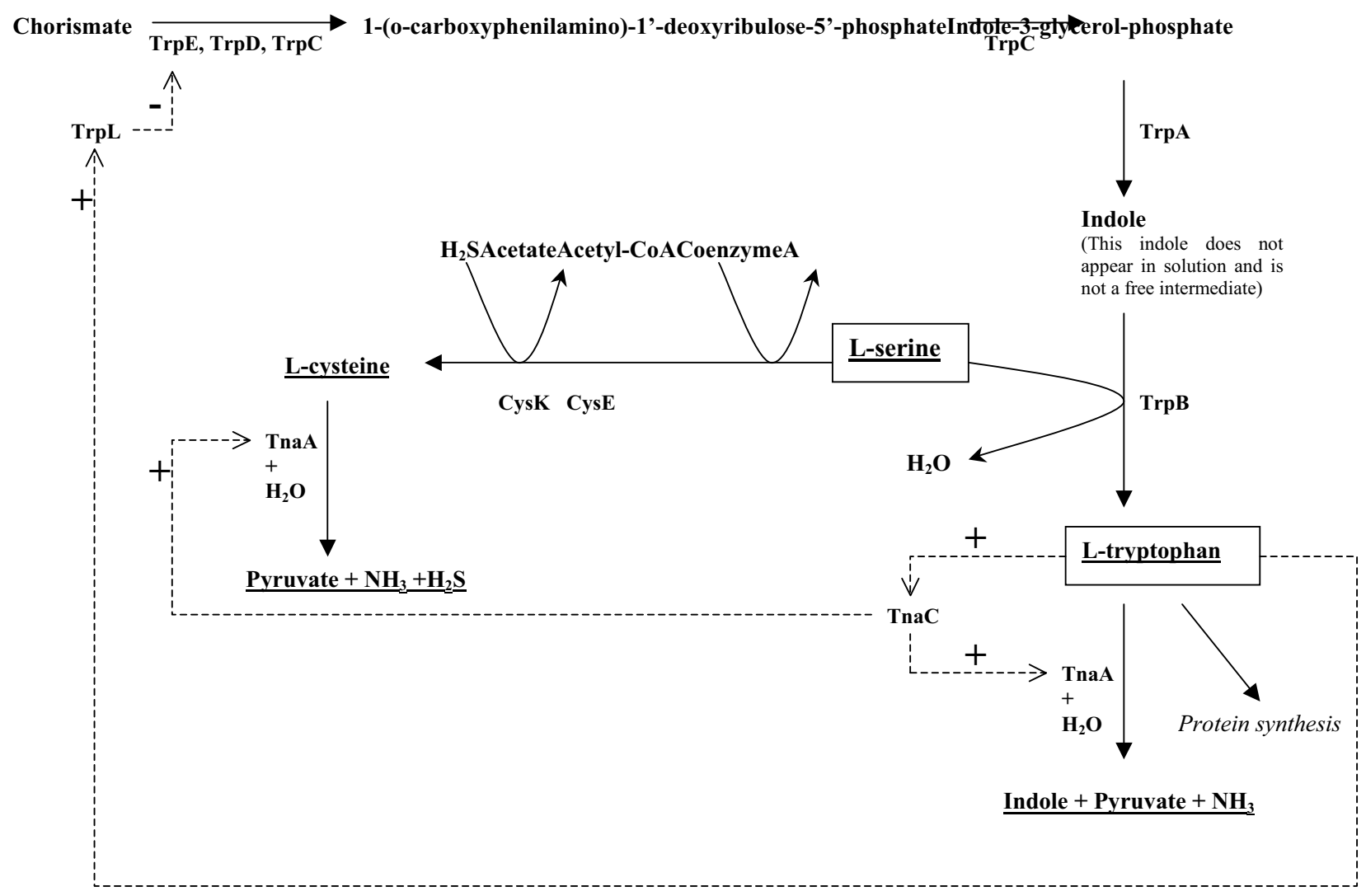

Figure I

Major components of the tryptophan pathway. Dashed lines indicate regulation.

reduced $40 \%$ and substratum coverage was increased 2.8 fold due to the flat nature of the biofilms with indole.

In 96 wells using crystal violet, addition of $1000 \mu \mathrm{M}$ indole in $\mathrm{LB}$ at $30^{\circ} \mathrm{C}$ also decreased the $8 \mathrm{~h}$ biofilm of $E$. coli ATCC 25404 by $46 \pm 22 \%$, of JM109 by $13 \pm 8 \%$, of TG1 by $77 \pm 13 \%$, and of XL1-Blue by $44 \pm 7 \%$. Hence, indole decreased $E$. coli biofilm formation.

We also explored biofilm formation with several tryptophan pathway mutants using the crystal violet stain method. Along with the $\operatorname{trpE}$, tnaC, and $\operatorname{trpL}$ strains, a strain with the isogenic mutation tnaA was also studied for its effect on biofilm formation because these genes are required for the synthesis of indole [24] (Fig. 1). Deletion of $\operatorname{trp} E$ and thaC (both decrease indole) increased biofilm formation in LB glu medium (Fig. 4) (5.4- and 3.9-fold at $24 \mathrm{~h}$, respectively). As expected, addition of 500 and 1000 $\mu \mathrm{M}$ indole to these two mutants reduced biofilm formation in a dose-dependent response to wild-type levels (2.1- and 4.4-fold reduction for $\operatorname{trp} E$ and 1.3- and 3.5-fold for tnaC, respectively). These results show reducing intra- cellular indole concentrations increases biofilm formation in E. coli. They also corroborate our earlier results in which the addition of $250 \mu \mathrm{M}$ indole reduced biofilm formation in the isogenic $y c e P$ and $y l i H$ mutants in LB and LB glu; these two strains overproduce biofilm as a result of reduced intracellular indole concentrations [14]. The deletion of tnaA did not affect biofilm formation in LB glu medium (Fig. 4) since tnaA is under catabolite repression.

To verify the 96-well biofilm assay, biofilm formation in LB glu was tested in a continuous flow system for the $\operatorname{trp} E$ mutant (rather than the repressed tnaA mutant), and the changes in biofilm were quantified using COMSTAT [26]. The $\operatorname{trpE}$ mutant displayed similar results in the flow cell as compared to the 96 wells as its deletion increased biomass (3.3-fold) and thickness (2-fold) (Fig. 3A/3C, Table 1).

\section{Dual-species biofilms}

Toluene o-monooxygenase (TOM) of the soil bacterium Burkholderia cepacia G4 converts indole into isoindigo [27]; hence, we hypothesized that if a bacterium other 


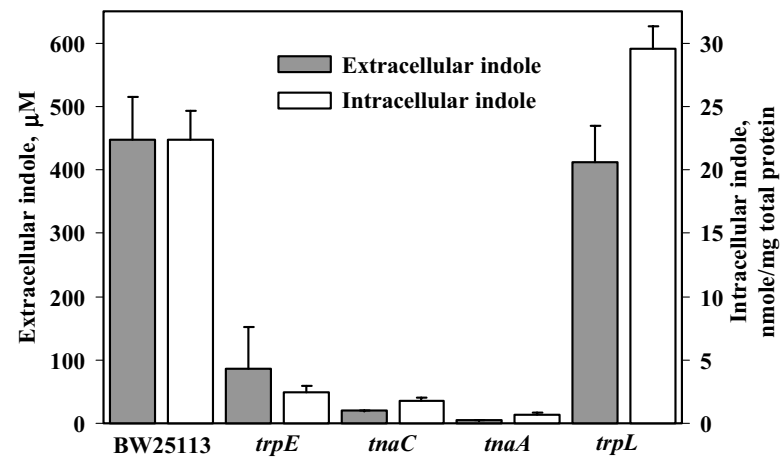

Figure 2

Intracellular and extracellular indole concentration in $L B$ for BW25II3, BW25II3 trpE, BW25II3 tnaC, BW25II3 tnaA, and BW25I I 3 trpL. Each experiment was performed in duplicate, and one standard deviation is shown.

than E. coli degraded indole and if indole represses E. coli biofilm formation, then $E$. coli would be present in higher numbers in a biofilm that had another bacterium which expressed TOM. TOM was integrated into the chromosome of the $P$. fluorescens strain to diminish the metabolic burden of this locus [28] and because this strain does not produce indole. At day 7 in the flow cell with LB medium, the dual species with the Pseudomonas expressing TOM showed 2- to 5 -fold more biofilm of red fluorescent protein (RFP) expressing E. coli K-12 ATCC25404/pGEM-T RFP than that in dual species without TOM in duplicate experiments (data not shown). Thus, including an organism that actively expressed TOM increased the amount of E. coli biofilm.

Similarly, when the Pseudomonas was tagged with RFP and E. coli with green fluorescent protein (GFP) so that both bacteria could be visualized, constitutive expression of TOM from the chromosome led to a 12-fold increase in $E$. coli biofilm after five days in the flow cell (Fig. 5 and Table 1). By expressing TOM to remove indole, both substratum coverage and mean thickness increased 10-fold; hence, sparse microcolonies became more mature colonies in the absence of the biofilm inhibitor indole. These corroborating sets of dual species biofilm results support our hypothesis that indole decreases biofilm formation with E. coli. Since a mixed biofilm formation of two species of Pseudomonas and E. coli was clearly observed (Fig. 5), this experiment also demonstrates that other bacteria may interfere with indole to control the biofilm formation of E. coli.

To ensure that extracellular indole is present, we ran the flow cell with wild-type K-12 alone and found that indole

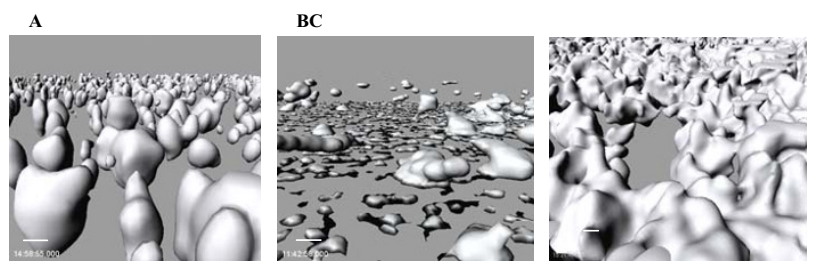

\section{Figure 3}

Biofilm formation in LB glu at $24 \mathrm{~h}$ in flow cells $(A)$ with wildtype K-12 BW25II3, (B) with wild-type K-12 BW25II 3 with $500 \mu \mathrm{M}$ indole, and (C) with K-12 BW25 I I 3 trpE. Scale bar is $5 \mu \mathrm{m}$.

concentrations increase from 17 to $250 \mu \mathrm{M}$ in 2 to $19 \mathrm{~h}$ then steadily decrease to $156 \mu \mathrm{M}$ in $43 \mathrm{~h}$, so substantial indole is present due to E. coli in our flow cells. Then, to show directly that the TOM-expressing pseudomonad decreased the indole levels, we measured extracellular indole at $8 \mathrm{~h}$ in LB medium (via high-pressure liquid chromatography, HPLC) for the RFP/GFP dual-culture system with TOM vs. no TOM and found that the indole concentration was decreased 22 -fold $(240 \pm 16 \mu \mathrm{M}$ for $E$. coli XL1Blue/pCM18/P. fluorescens 2-79/pHKT3 that lacks TOM vs. $11 \pm 3 \mu \mathrm{M}$ for E. coli XL1-Blue/pCM18/P. fluorescens 2$79 \mathrm{TOM} / \mathrm{pHKT} 3$ expressing TOM). The cell growth rate was $0.45 \pm 0.02 / \mathrm{h}$ for $P$. fluorescens $2-79 /$ pHKT3 and 0.52 $\pm 0.02 / \mathrm{h}$ for $P$. fluorescens $2-79 \mathrm{TOM} / \mathrm{pHKT} 3$; hence, the extracellular indole concentrations were decreased by cloning TOM, and the changes in E. coli biofilm formation are due to a reduction in extracellular indole concentrations.

\section{Indole and pseudomonad biofilms}

To determine if indole is a signal for pseudomonads, too, we added indole to $P$. aeruginosa. Indole at $500 \mu \mathrm{M}$ increased biofilm formation 1.4-fold and $1000 \mu \mathrm{M}$ increased biofilm formation 2.2-fold (crystal violet density $1.0 \pm 0.2$ vs. $2.2 \pm 0.2$ ); hence, indole, although not synthesized by $P$. aeruginosa (extracellular concentration was $0 \mu \mathrm{M}$ ), is a signal that stimulates biofilm in this strain. In addition, removing indole $(1000 \mu \mathrm{M})$ by expressing TOM in P. fluorescens 2-79 results in a 5.6-fold reduction in P. fluorescens biomass compared to P. fluorescens 2-79 without TOM which indicates that indole stimulates biofilm formation in this pseudomonad (crystal violet density $0.45 \pm 0.07$ vs. $0.08 \pm 0.01)$.

\section{External indole decreases motility and the deletion of trpE or tnaC increases motility}

To investigate the cause of the reduction in biofilm due to indole, motility was studied since it positively influences biofilm formation in E. coli $[29,30]$. The deletion of $\operatorname{trp} E$ 
Table I: Biofilm COMSTAT flow cell measurements for E. coli BW25 I I3 and its isogenic mutants LB glu medium at $24 \mathrm{~h}$ and for the dual species ( $E$. coli/P. fluorescens) biofilm in LB medium after 5 days

\begin{tabular}{|c|c|c|c|c|c|}
\hline Conditions & Strains & Biomass, $\mu \mathrm{m}^{3} / \mu \mathrm{m}^{2}$ & $\begin{array}{l}\text { Substratum } \\
\text { coverage, \% }\end{array}$ & $\begin{array}{c}\text { Mean } \\
\text { thickness, } \mu \mathrm{m}\end{array}$ & $\begin{array}{l}\text { Roughness } \\
\text { coefficient }\end{array}$ \\
\hline \multirow{4}{*}{$\begin{array}{l}\text { Single species of BW } 251 / 3 \\
\text { and its isogenic mutant }\end{array}$} & BW25II3 & $9 \pm 5$ & $8 \pm 9$ & $24 \pm 8$ & $0.6 \pm 0.4$ \\
\hline & BW25I I 3 with DMF (control for indole) & $6.4 \pm 3$ & $6.5 \pm 7$ & $21 \pm 8$ & $0.5 \pm 0.5$ \\
\hline & BW25II 3 with $500 \mu \mathrm{M}$ indole & $4 \pm 1.5$ & $18 \pm 6$ & $25 \pm 6$ & $0.9 \pm 0.6$ \\
\hline & BW $25113 \operatorname{trp} E$ & $30 \pm 7$ & $13 \pm 6$ & $46 \pm 3.5$ & $0.3 \pm 0.1$ \\
\hline \multirow[t]{2}{*}{ Dual species with TOM } & P. fluorescens 2-79TOM/pHKT3 & $0.06 \pm 0.05$ & $0.90 \pm 0.56$ & $0.14 \pm 0.13$ & $1.97 \pm 0.02$ \\
\hline & E. coli K-I2 XLI-Blue/pCMI8 & $6.63 \pm 2.67$ & $21.52 \pm 10.49$ & $13.95 \pm 5.67$ & $0.90 \pm 0.34$ \\
\hline \multirow[t]{2}{*}{ Dual species without TOM } & P. fluorescens 2-79/pHKT3 & $0.03 \pm 0.01$ & $0.64 \pm 0.16$ & $0.04 \pm 0.02$ & $1.99 \pm 0.01$ \\
\hline & E. coli K-12 XLI-Blue/pCMI8 & $0.56 \pm 0.51$ & $1.81 \pm 1.23$ & $1.04 \pm 0.68$ & $1.87 \pm 0.06$ \\
\hline
\end{tabular}

and tnaC increased motility (3.2-fold for trpE and 4.7-fold for tnaC) compared with the isogenic wild-type strain (Fig. 6). Therefore the reduction in intracellular indole concentration through the deletion of $\operatorname{trpE}$ and tnaC increases motility which leads to the increased biofilm formation; hence, indole decreases motility. To corroborate that indole decreases motility, the motility of wildtype E. coli and its trpE and tnaC mutants were tested upon addition of $500 \mu \mathrm{M}$ indole; the addition of indole decreased motility by 30 to $40 \%$ for these strains (Fig. 6), so the enhanced motility due to a reduction of indole could be diminished by direct addition of indole. Hence, indole reduces motility in $E$. coli, and this reduced motility appears be one of causes of the reduced biofilm formation.

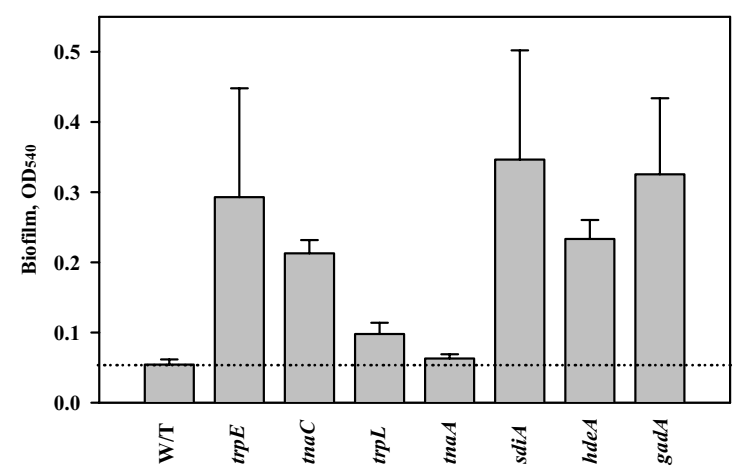

\section{Figure 4}

Effect of the trpE, tnaC, trpL, tnaA, sdiA, hdeA, and gadA mutations on biofilm formation in LB glu media. Biomass measured at $540 \mathrm{~nm}$ after $24 \mathrm{~h}$. Each experiment was repeated two or four times, and one standard deviation is shown.
Indole is a global regulator in biofilm formation in E. coli through SdiA and acid resistance

To investigate the genetic basis of indole regulation of biofilms, we performed three sets of microarray experiments: (i) direct addition of $600 \mu \mathrm{M}$ indole to K-12 $y c e P$ in LB glu since this strain has elevated biofilm formation due to low intracellular indole and the biofilm responds to added indole [14] (note two independent sets of microarrays were used for this experiment), (ii) a comparison of K-12 $\operatorname{trpE}$ vs. K-12 wild-type in LB glu since the trpE cells had reduced indole and had elevated biofilm in LB glu at $24 \mathrm{~h}$, and (iii) K-12 tnaA vs. K-12 wild-type in LB since the tnaA cells also had little detectable indole in this medium. Glass wool was used to increase the surface area so that RNA could be readily obtained for the microarrays. The most significantly induced and repressed genes are shown
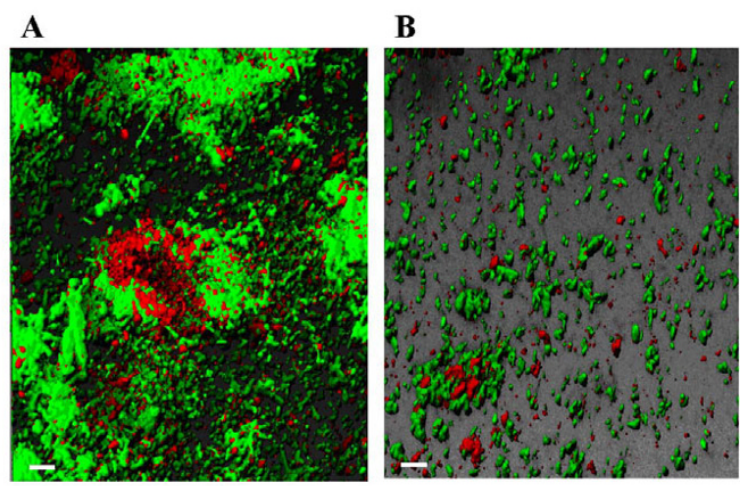

Figure 5

Biofilm formation in LB after 5 days in flow cells for (A) dual species of $E$. coli K-I 2 XLI-Blue/pCMI 8 (green due to GFP) and $P$. fluorescens 2-79TOM/pHKT3 expressing TOM (red due to RFP), and (B) dual species of $E$. coli K-I 2 XLI-Blue/ PCMI 8 (green due to GFP) and $P$. fluorescens 2-79/pHKT3 (red due to RFP). Scale bar is $10 \mu \mathrm{m}$. 
in Table 2. Thirteen, 43, and 34 genes were differentially induced (greater than 2 fold) and 17, 21, and 141 genes were differentially repressed (greater than 2 fold) upon indole addition, deleting $\operatorname{trp} E$, or deleting tnaA, respectively.

Notably SdiA was one of the most-induced genes (2.9fold) upon addition of $600 \mu \mathrm{M}$ indole (Table 2). Since SdiA is predicted to inhibit chemotaxis and motility based on microarrays [21], it was expected that a sdiA deletion should lead to enhanced motility and biofilm formation. Corroborating our microarray results, the motility of the isogenic sdiA strain was increased $2.0 \pm 0.6$-fold, and biofilm formation was increased $6 \pm 2$-fold in LB glu at $37^{\circ} \mathrm{C}$ at $24 \mathrm{~h}$ (Fig. 4) and increased 3.5-fold in LB at $30^{\circ} \mathrm{C}$ at 24 $\mathrm{h}$. In addition, for short time experiments $(8 \mathrm{~h})$, the sdiA mutation caused a 51-fold increase biofilm formation at $30^{\circ} \mathrm{C}$ in LB (absorbance at $540 \mathrm{~nm}$ of $1.53 \pm 0.07$ vs. 0.03 \pm 0.01 ); however, there was no change in biofilm formation upon deleting sdiA at $37^{\circ} \mathrm{C}$ with LB. Hence, SdiA represses motility and biofilm formation.

As expected, the addition of $1000 \mu \mathrm{M}$ indole to the sdiA mutant in LB glu did not appreciably decrease its elevated biofilm levels (data not shown). Hence, indole induces expression of SdiA which appears to result in SdiA repressing biofilm formation by decreasing motility. Similarly, the $\operatorname{trp} E$ mutation, which diminishes intracellular indole, led to both increased biofilm (Fig. 3C) and motility (Fig. 6) indicating again that indole is a biofilm inhibitor that controls biofilms by reducing motility. However, the addition of indole also decreased motility of the sdiA mutant (Fig. 6) so that other factors are involved in the motility reduction with indole. Recently, it has been reported that indole is responsible for delaying cell division, and addition of $4 \mathrm{mM}$ indole stopped E. coli cell division [9]. Therefore, we propose that indole may decrease motility through cell division interference.

\section{Indole controls sdiA-mediated transcription}

To corroborate that indole influences SdiA and the genes it controls, we tested the ability of indole to alter SdiAinfluenced transcription of the ftsQ2p (or $f t s Q p_{2}$ ) promoter; this promoter is one of the few promoters SdiA is known to directly induce $[19,31]$. The addition of 1000 $\mu \mathrm{M}$ indole to $E$. coli UT481/pCX39 led to a $33 \pm 15 \%$ (average of five independent cultures) decrease in $f t s Q 2 p$ expression which agrees with the $30 \%$ reduction seen by García-Lara et al. [31] due to the unknown stationaryphase factor. Therefore, indole affects SdiA-mediated transcription. As expected, indole addition to the isogenic sdiA mutant (E. coli WX2/pCX39) had no effect on ftsQ2p expression (the absolute level of $\beta$-galactosidase was also $48 \%$ lower in this mutant); hence, indole either binds SdiA directly or through some intermediate and regulates

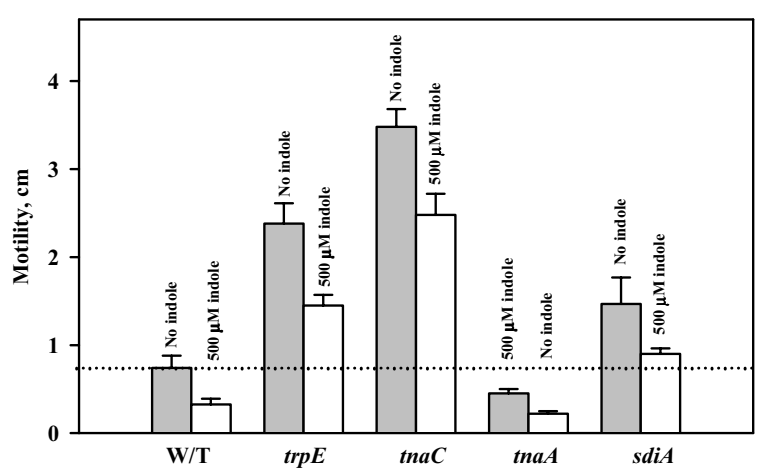

\section{Figure 6}

Effect of indole $(500 \mu \mathrm{M})$ on the motility of BW25 I I 3 wildtype (W/T), BW25I I3 trpE, BW25 I 3 thaC, BW25 I I 3 tnaA, and BW25II 3 sdiA. Motility halos were measured at $8 \mathrm{~h}$. Each experiment was repeated two or four times, and one standard deviation is shown. DMF $(0.1 \%, v / v)$ was used as a negative control.

SdiA-mediated transcription in the absence of acyl-homoserine lactones.

\section{Homoserine lactones and E. coli biofilm formation}

Since SdiA binds four different homoserine lactone signals that E. coli cannot synthesize $[22,23]$, we tested the ability of homoserine lactone signals to control biofilm formation to cement the link between SdiA and biofilms. As with indole, adding three naturally-occurring homoserine lactone signals ( $N$-butyryl- $D L$-homoserine lactone [32], $N$-hexanoyl-DL-homoserine lactone [33], and $N$ octanoyl-DL-homoserine lactone [33]) inhibited K-12 biofilm formation in LB medium in a dose-dependent manner without inhibiting growth by $25 \%, 27 \%$, and $18 \%$, respectively; however, the isogenic sdiA mutant does not respond to the homoserine lactone signals. N-(3oxooctaneoyl)- $D L$-homoserine lactone, $N$-decanoyl- $D L$ homoserine lactone, and $N$-dodecanoyl- $D L$-homoserine lactone did not change biofilm formation of either the wild type and sdiA mutant. These results were repeated 5 times for $N$-butyryl-DL-homoserine lactone and each time there was consistent and significant reduction in E. coli biofilm formation as long as SdiA was present. Also, the addition of $10 \mu \mathrm{M} N$-butyryl-DL-homoserine lactone caused a $40 \pm 7 \%$ increase in $f t s Q 2 p$ expression which confirms the homoserine lactone signal binds SdiA, while the addition of the $10 \mu \mathrm{M} \mathrm{N}$-butyryl- $D L$-homoserine lactone to the isogenic sdiA mutant had no effect on $f t s Q 2 p$ expression. Hence, E. coli responds to homoserine lactone signals by altering its biofilm formation and it does so through SdiA. 
Table 2: Partial list of genes induced and repressed more than 2-fold after $24 \mathrm{~h}$ in (i) $\mathrm{K}-12$ yceP biofilms upon addition of $600 \mu \mathrm{M}$ indole in LB glu medium (experiment performed in duplicate, and one standard deviation is shown), (ii) K-I 2 biofilms due to the trpE mutation in LB glu medium, and (iii) K-I 2 biofilms due to the tnaA mutation in LB medium.

\begin{tabular}{|c|c|c|c|c|c|c|}
\hline Gene & b \# & $\begin{array}{l}\text { Fold change upon } \\
\text { indole addition }\end{array}$ & $\begin{array}{l}\text { Fold change upon } \\
\text { trpE deletion }\end{array}$ & $\begin{array}{l}\text { Fold change upon } \\
\text { tnaA deletion }\end{array}$ & Description & $\begin{array}{l}\text { Protein } \\
\text { Size, aa }\end{array}$ \\
\hline \multicolumn{7}{|c|}{ Transcription } \\
\hline sdiA & b1916 & $2.9 \pm 0.8$ & $1.0 *$ & 1.2 & $\begin{array}{l}\text { AHL transcriptional activator (LuxR/TraR } \\
\text { family) }\end{array}$ & 240 \\
\hline ygaV & $b 2667$ & $2.2 \pm 0.2$ & $1 . I^{*}$ & $-1 . I^{*}$ & hypothetical protein & 99 \\
\hline soxs & $b 4062$ & $2.3 \pm 0.3$ & -2.8 & -1.2 & regulation of superoxide response regulon & 107 \\
\hline $\operatorname{csp} A$ & b3556 & $1.8 \pm 0.4$ & -4.6 & $-1.2 *$ & $\begin{array}{l}\text { cold shock protein } 7.4 \text {, transcriptional activator } \\
\text { of hns }\end{array}$ & 70 \\
\hline$m t / R$ & b360I & $1.3^{*} \pm 0.4$ & -2.6 & $-1.4^{*}$ & MtIR transcriptional repressor & 195 \\
\hline yjcT & $b 4084$ & $-1.1 * \pm 0.1$ & $1.5^{*}$ & -3.5 & D-allose kinase & 309 \\
\hline rhoL & b3782 & $2.2 \pm 0.1$ & $-1.1^{*}$ & $1.1^{*}$ & rho operon leader peptide & 33 \\
\hline \multicolumn{7}{|c|}{ Cell motility and secretion } \\
\hline hha & b0460 & $4.9 \pm 0.0$ & -1.4 & -1.4 & haemolysin expression modulating protein & 72 \\
\hline ybaj & b046I & $5.2 \pm 0.8$ & $-1.1^{*}$ & $1.0 *$ & conserved hypothetical protein & 124 \\
\hline$m q s R$ & b3022 & $2.8 \pm 0.7$ & $1.1 *$ & 1.4 & $\begin{array}{l}\text { master regulator of chemotaxis via Al-2; } \\
\text { interacts with QseB }\end{array}$ & 98 \\
\hline$s f m A$ & b0530 & $-1.3 * \pm 0.1$ & $1.0 *$ & -2.3 & putative fimbrial-like protein & 191 \\
\hline$s f m C$ & $b 0531$ & $-1.1 * \pm 0.1$ & $-1.1^{*}$ & -2.3 & putative chaperone & 230 \\
\hline$s f m H$ & b0533 & $-1.2 * \pm 0.1$ & $1.1 *$ & -2.0 & fimbrial assembly protein & 325 \\
\hline flgA & b1072 & $1.1 * \pm 0.1$ & $1.2^{*}$ & -2.1 & $\begin{array}{l}\text { flagellar biosynthesis; assembly of basal-body } \\
\text { periplasmic P ring }\end{array}$ & 219 \\
\hline yehA & $b 2108$ & $1 . I^{*} \pm 0.0$ & $-1.1^{*}$ & -2.1 & hypothetical protein & 344 \\
\hline yhcA & $b 3215$ & $1.1 * \pm 0.0$ & -1.7 & -2.0 & putative chaperone & 224 \\
\hline yfcP & $b 2333$ & $1.1 * \pm 0.1$ & $1.3^{*}$ & -2.0 & putative fimbrial-like protein & 179 \\
\hline \multicolumn{7}{|c|}{ Colanic acid synthesis genes } \\
\hline ypdl & $b 2376$ & $-1.2^{*} \pm 0.2$ & $1.3^{*}$ & -2.5 & Ypdl colanic acid synthesis lipoprotein & 91 \\
\hline \multicolumn{7}{|c|}{ Acid resistance } \\
\hline gadE & $b 3512$ & $-4.3 \pm 1.4$ & -1.6 & I.I* & $\begin{array}{l}\text { activator of acid resistance genes and putative } \\
\text { LuxR transcriptional activator }\end{array}$ & 175 \\
\hline $\operatorname{gad} A$ & $b 3517$ & $-4.0 \pm 1.3$ & -2.3 & $1.2^{*}$ & $\begin{array}{l}\text { glutamate decarboxylase A, isozyme, PLP- } \\
\text { dependent }\end{array}$ & 466 \\
\hline $\operatorname{gadB}$ & b|493 & $-2.8 \pm 0.7$ & -2.6 & $1.2^{*}$ & glutamate decarboxylase isozyme & 466 \\
\hline $\operatorname{gadC}$ & bl492 & $-3.7 \pm 0.0$ & -1.6 & $1.2^{*}$ & $\begin{array}{l}\text { acid sensitivity protein, putative transporter, } \\
\text { encoding a } \gamma \text {-aminobutyrate antiporter }\end{array}$ & 511 \\
\hline $\operatorname{gad} X$ & $b 3516$ & $-2.0 \pm 0.4$ & -1.2 & -1.2 & activator of gadA and gadBC & 274 \\
\hline hdeA & $b 3510$ & $-4.8 \pm 0.2$ & -2.3 & $1.0^{*}$ & $\begin{array}{l}\text { periplasmic chaperone of acid-denatured } \\
\text { protein }\end{array}$ & 110 \\
\hline$h d e B$ & b3509 & $-3.9 \pm 0.6$ & -2.3 & $1.2^{*}$ & $\begin{array}{l}\text { IOK-L protein, periplasmic protein related to } \\
\text { acid resistance protein }\end{array}$ & 112 \\
\hline hdeD & $b 3511$ & $-3.0 \pm 0.5$ & -1.6 & -1.5 & protein involved in acid resistance & 190 \\
\hline \multicolumn{7}{|c|}{ Phage-related genes } \\
\hline $\operatorname{cspl}$ & bl552 & $1.8 \pm 0.7$ & $1.0 *$ & -3.7 & Qin prophage; cold shock-like protein & 70 \\
\hline урјF & $b 2646$ & $1.4^{*} \pm 0.2$ & $1.2^{*}$ & -12.1 & CP4-57 prophage & 109 \\
\hline ymfl & bl|43 & $1 . I^{*} \pm 0.1$ & $1 . I^{*}$ & -5.7 & El4 prophage & 113 \\
\hline ydaY & b|366 & $1.0 * \pm 0.0$ & $1.0^{*}$ & -4.6 & Rac prophage & 119 \\
\hline$y d f P$ & bl553 & $-1.2^{*} \pm 0.2$ & $1.2^{*}$ & -2.6 & Qin prophage & 165 \\
\hline ydfE & b। 577 & $1.0 * \pm 0.1$ & $1.3^{*}$ & -2.5 & Qin prophage & 255 \\
\hline yeeV & b2005 & $-1.5 * \pm 0.5$ & $1.1^{*}$ & -2.5 & CP4-44 prophage & 124 \\
\hline stfE & bl I57 & $1.4^{*} \pm 0.4$ & $-1.1 *$ & -2.3 & EI4 prophage; putative tail fiber protein & 166 \\
\hline$b \mid 364$ & $b \mid 364$ & $1.2 * \pm 0.1$ & $1.1 *$ & -2.3 & Rac prophage & 93 \\
\hline yfjW & $b 2642$ & $1.4^{*} \pm 0.4$ & $-1.1^{*}$ & -2.1 & CP4-57 prophage & 567 \\
\hline yeeU & b2004 & $1.0 * \pm 0.0$ & $-1.1^{*}$ & -2.0 & CP4-44 prophage; putative structural protein & 122 \\
\hline yfj $T$ & $b 2637$ & $-1.4^{*} \pm 0.6$ & $1.1 *$ & -2.0 & CP4-57 prophage & 155 \\
\hline ynaE & b|375 & $1.8 \pm 0.6$ & -1.9 & -2.0 & Rac prophage & 88 \\
\hline \multicolumn{7}{|c|}{ Amino acid transport and metabolism } \\
\hline tnaA & b3708 & $1.7 \pm 0.0$ & $-1.3^{*}$ & -14.9 & tryptophan deaminase, PLP-dependent & 476 \\
\hline tnaC & b3707 & $1.5 \pm 1.1$ & $1.1 *$ & 32.0 & tryptophanase leader peptide & 24 \\
\hline$m t r$ & $b 3161$ & $-1.1^{*} \pm 0.1$ & -1.3 & -5.7 & Mtr tryptophan ArAAP transporter & 414 \\
\hline
\end{tabular}


Table 2: Partial list of genes induced and repressed more than 2-fold after $24 \mathrm{~h}$ in (i) K-12 yceP biofilms upon addition of $600 \mu \mathrm{M}$ indole in LB glu medium (experiment performed in duplicate, and one standard deviation is shown), (ii) K-I 2 biofilms due to the trpE mutation in LB glu medium, and (iii) K-I 2 biofilms due to the tnaA mutation in LB medium. (Continued)

\begin{tabular}{|c|c|c|c|c|c|c|}
\hline aroP & b0II2 & $1.0^{*} \pm 0.0$ & $-1.2^{*}$ & -5.3 & $\begin{array}{l}\text { AroP phenylalanine/tyrosine/tryptophan APC } \\
\text { transporter }\end{array}$ & 457 \\
\hline proc & b0386 & $-1.2 \pm 0.0$ & $1.0 *$ & -3.0 & pyrroline-5-carboxylate-reductase & 269 \\
\hline \multicolumn{7}{|c|}{ Carbohydrate transport and metabolism } \\
\hline melB & $b 4120$ & $1.2^{*} \pm 0.1$ & $1.1 *$ & -7.5 & melibiose permease II & 469 \\
\hline eno & $b 2779$ & $-1.9 \pm 0.2$ & $-1.2^{*}$ & I.I* & Enolase & 432 \\
\hline yegB & b2077 & $-1.2^{*} \pm 0.2$ & $1.1 *$ & -3.2 & multidrug transport protein (MFS family) & \\
\hline $\operatorname{prpB}$ & b033I & $-2.4 \pm 0.6$ & $-1.1 *$ & $1.0 *$ & $\begin{array}{l}\text { putative carboxyphosphonoenolpyruvate } \\
\text { mutase }\end{array}$ & 296 \\
\hline \multicolumn{7}{|c|}{ Other metabolism } \\
\hline$h t r L$ & $b 3618$ & $2.2 \pm 0.1$ & $1.1^{*}$ & $-1.2^{*}$ & involved in lipopolysaccharide biosynthesis & 290 \\
\hline pyrG & $b 2780$ & $-2.2 \pm 0.2$ & $1.0 *$ & $1.0 *$ & CTP synthetase & 545 \\
\hline phel & $b 2598$ & $-1.2 \pm 0.1$ & -4.9 & 2.3 & $\begin{array}{l}\text { chorismate mutase-P-prephenate dehydratase } \\
\text { leader peptide }\end{array}$ & 15 \\
\hline yodA & b|973 & $\mathrm{I} .5 \pm 0.4$ & $1.0 *$ & -7.5 & cadmium-induced metal binding protein & 216 \\
\hline chaA & $b \mid 216$ & $-1.4^{*} \pm 0.4$ & $1.2^{*}$ & -7.0 & sodium-calcium/proton antiporter & 366 \\
\hline nhaA & $b 0019$ & $-1.2 * \pm 0.0$ & -1.4 & -3.2 & $\mathrm{Na}+/ \mathrm{H}$ antiporter, $\mathrm{pH}$ dependent & 388 \\
\hline ybdS & $b 0612$ & $-1.3^{*} \pm 0.3$ & $-1.2^{*}$ & -3.2 & citrate carrier & 487 \\
\hline \multicolumn{7}{|c|}{ Energy production and conversion } \\
\hline$r s \times A$ & b1627 & $1 . I^{*} \pm 0.0$ & $-1.1 *$ & -14.9 & $\begin{array}{l}\text { integral membrane protein of SoxR-reducing } \\
\text { complex }\end{array}$ & 193 \\
\hline ynbA & $b \mid 408$ & $1.1 * \pm 0.0$ & $1.4^{*}$ & -4.6 & $\begin{array}{l}\text { putative diacylglycerol } \\
\text { cholinephosphotransferase }\end{array}$ & 203 \\
\hline \multicolumn{7}{|c|}{ Posttranslational modification, protein turnover, chaperones } \\
\hline$h t p X$ & b1829 & $2.8 \pm 1.1$ & $-1.1^{*}$ & I.I* & heat shock protein, integral membrane protein & 293 \\
\hline \multicolumn{7}{|c|}{ Translation } \\
\hline ksgA & b005I & $-1.9 \pm 0.6$ & $-1.3^{*}$ & -3.0 & $\begin{array}{l}\text { S-adenosylmethionine-6-N',N'-adenosyl (rRNA) } \\
\text { dimethyltransferase }\end{array}$ & 273 \\
\hline infA & b0884 & $1.0 * \pm 0.1$ & $-1.3^{*}$ & -3.0 & protein chain initiation factor IF-I & 72 \\
\hline \multicolumn{7}{|c|}{ Defense mechanisms } \\
\hline soda & b3908 & $1.2^{*} \pm 0.3$ & -3.2 & $\mathrm{I} . \mathrm{I}^{*}$ & superoxide dismutase, manganese & 206 \\
\hline \multicolumn{7}{|c|}{ Poorly-characterized genes } \\
\hline$y \subset f R$ & $b 1112$ & $2.7 \pm 0.8$ & $1.0 *$ & -1.4 & hypothetical protein & 85 \\
\hline ylad & b0459 & $2.3 \pm 0.3$ & $1.0 *$ & $-2.8^{*}$ & maltose O-acetyltransferase & 183 \\
\hline yebE & b1846 & $2.4 \pm 0.1$ & $1 . I^{*}$ & -2.1 & hypothetical protein & 219 \\
\hline ynd & b|436 & $2.7 \pm 0.5$ & $-1.1 *$ & -1.2 & hypothetical protein & 76 \\
\hline yejG & $b 2181$ & $2.4 \pm 0.4$ & -1.5 & $-1.2^{*}$ & hypothetical protein & 114 \\
\hline ybjM & b0848 & $-1.3 * \pm 0.3$ & -1.4 & -8.6 & hypothetical protein & 125 \\
\hline b0309 & b0309 & $-1.5^{*} \pm 0.6$ & -1.4 & -4.6 & hypothetical protein & 70 \\
\hline ypjB & $b 2649$ & $1.1 * \pm 0.0$ & $1.2^{*}$ & -3.7 & hypothetical protein & 263 \\
\hline$a p a G$ & $b 0050$ & $-2.2 \pm 0.9$ & -1.3 & -3.7 & hypothetical protein & 125 \\
\hline ydiY & bl 722 & $-1.1 * \pm 0.1$ & $1.2^{*}$ & -3.5 & hypothetical protein & 252 \\
\hline$y m f A$ & bl 122 & $-1.1 * \pm 0.1$ & $1.0 *$ & -3.5 & hypothetical protein & 156 \\
\hline yeil & $b 2174$ & $1.2^{*} \pm 0.1$ & $-1.2^{*}$ & -3.0 & hypothetical protein & 249 \\
\hline yaho & b0329 & $-1.8 \pm 0.4$ & 1.3 & 1.3 & hypothetical protein & 91 \\
\hline psiF & b0384 & $-1.9 \pm 0.3$ & $-1.1 *$ & -1.3 & $\begin{array}{l}\text { induced by phosphate starvation; pho regulon } \\
\text { member, requiring phoRB system }\end{array}$ & 112 \\
\hline ycdF & bl005 & $-2.0 \pm 0.1$ & $1.1 *$ & -1.2 & hypothetical protein & 76 \\
\hline yciG & bl 259 & $-2.1 \pm 0.1$ & $1.2^{*}$ & 1.6 & hypothetical protein & 78 \\
\hline$y c g Z$ & $b \mid 164$ & $-2.9 \pm 0.6$ & 1.3 & 1.7 & hypothetical protein & 78 \\
\hline$y m g C$ & bl167 & $-2.1 \pm 0.3$ & $1.2^{*}$ & 1.5 & hypothetical protein & 82 \\
\hline ymgA & $b \mid 165$ & $-2.4 \pm 1.3$ & 1.1 & 1.7 & hypothetical protein & 90 \\
\hline$y m g B$ & bl166 & $-5.2 \pm 1.3$ & 1.2 & 1.5 & $\begin{array}{l}\text { hypothetical protein, putative acid-resistance } \\
\text { protein }\end{array}$ & 88 \\
\hline
\end{tabular}

Full data available using GEO accession number 4562. Asterisk indicates p value greater than 0.05 (data are less reliable but included for completeness). Negative values indicate repressed genes. b \# indicates the Blattner number for each gene. Boldface indicates most significant fold changes. 


\section{Indole and acid resistance}

Indole addition also repressed the glutamate decarboxylase acid-resistance genes gadABCEX 2- to 4-fold (Table 2). GadABC are regulated by GadE and protect $E$. coli at pH 2 and below which allows the bacterium to colonize the gastrointestinal tract [34]. Also, the other known acidresistance genes and hdeABD (which function as chaperones to prevent aggregation of periplasmic proteins under extremely acidic conditions [35]) were repressed 3- to 5fold by indole (Table 2). Hence, we surmised that indole decreases acid resistance. This hypothesis was tested using LB medium at $\mathrm{pH} 2.5$ and found that the $\operatorname{trpE}$ mutant (which produces 10 times less indole, Fig. 2) was 53 times less sensitive to $\mathrm{pH} 2.5$ than the wild-type, while sdiA mutant showed 17-fold less survival (Fig. 7). As expected, the positive controls, cells with hdeA and gadA mutations displayed increased acid sensitivity (Fig. 7). To show clearly that indole is directly related to acid resistance, we investigated whether indole addition affects E. coli $\mathrm{K}-12$ survival at $\mathrm{pH} 2.5$. Addition of $2 \mathrm{mM}$ indole to the wildtype strain decreased survival by 350 to 650 -fold. However, addition of $2 \mathrm{mM}$ indole to the sdiA mutant did not appreciably change acid survival (3.9-fold decrease for sdiA mutant). The results also support our hypothesis that indole controls biofilm formation and acid resistance via SdiA.

\section{tnaA and trpE microarrays}

The deletion of tnaA led to more extensive differential gene expression compared to the deletion of $\operatorname{trpE}$ and indole addition to the $y c e P$ mutant. As expected, tnaC was highly induced (32-fold, Table 2) indicating high concentrations of tryptophan arise when TnaA is not active. $m t r$, which encodes the tryptophan importer [36], was also downregulated, again supporting that tryptophan concentrations were high. The repression of 13 phage-related genes (Table 2) upon deleting tnaA suggests a possible link in biofilm formation and phage-related genes as reported previously in $P$. aeruginosa [37]. The repression of seven motility genes in the tnaA mutant (Table 2) may be the reason the tnaA mutant does not increase biofilm formation despite low intracellular indole (Fig. 2). In addition, 22 translation and RNA genes were induced in the tnaA mutant, and 36 translation and RNA genes were also induced in the $\operatorname{trp} E$ mutant.

To corroborate further the microarray results (i.e., the genes identified as differentially-expressed in the microarrays should impact biofilm formation upon deletion), two independent cultures of the isogenic E. coli $\mathrm{K}-12$ mutants gadA and hdeA were tested for altered biofilm formation using the 96-well crystal violet assay in LB and LB glu medium. Notably, the most significant changes occurred in LB glu medium where there were significant increases in biofilm (Fig. 4).

\section{Discussion}

In this study we demonstrate that both indole and $\mathrm{N}$-acylhomoserine lactones are signals in the formation of $E$. coli biofilms. Indole extracellular concentrations are significant in rich culture broths, and it appears indole negatively regulates $E$. coli biofilm formation by reducing motility (Fig. 6) and by influencing acid resistance. The differences in the architecture upon indole addition (Fig. $3 \mathrm{~A} / 3 \mathrm{~B}$ ) are most likely due to differences in cell motility since we have found differences in $E$. coli biofilm architecture between strains with different motility phenotypes [30], and the architecture of the strain without indole displayed similarities with high-motility strains while architecture with indole was similar to the architecture for low motility strains. Hence, just as one needs an accelerator as well as a brake to control an automobile, it appears E. coli cells control biofilm formation using an inducer (AI-2 [4]) as well as a repressor (indole). In contrast, indole stimulates biofilm formation for $P$. aeruginosa.

Along with stimulating pseudomonad biofilm formation, the two sets of dual-species biofilm results demonstrate that indole is an interspecies signal that can be manipulated by other bacteria (note there are 27 genera with a putative tryptophanase with a $30 \%$ identity to that of $E$. coli). This type of signal manipulation has been shown for AI-2 with E. coli and V. harveyi [38] as well as for homoserine lactone with Erwinia carotovora and Bacillus thuringiensis [39]; hence, competition and control for signals appears to be intense in biofilms. This competition extends beyond procaryotes as eucaryotes are well known for manipulating the quorum sensing signals of bacteria, too. For example, algae block bacterial biofilm formation by controlling both homoserine lactone and AI-2 signaling via furanones [40], and mammals (including

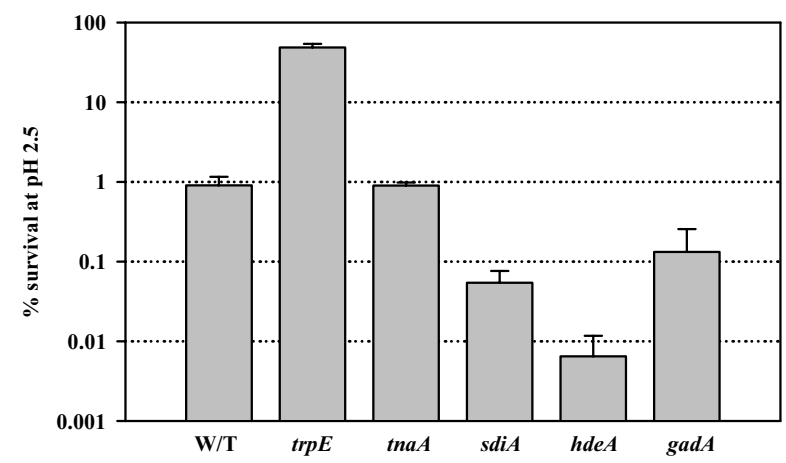

\section{Figure 7}

Acid resistance of BW25 I I 3 wild-type $(\mathrm{W} / \mathrm{T})$ and various knockout mutants in LB medium $(\mathrm{pH} 2.5)$ at $37^{\circ} \mathrm{C}$. Each experiment was repeated two or four times and one standard deviation is shown. 
humans) block homoserine lactone signaling via lactonase in sera [41]. Furthermore, it appears that the mechanism by which procaryotes (such as the pseudomonads in this study) manipulate the biofilm signal indole is through the relaxed substrate range of many dioxygenases and monooxygenases found in bacteria that bring about indole hydroxylation [27]; i.e., we propose that some of the oxygenases bacteria use for catabolism [42] have also evolved to regulate concentrations of the inter-species signal indole by removing it via precipitation: competitors that wish to remove indole simply oxidize it in one step to indigo which is insoluble and hence leaves the system.

The results presented here are also important in that they show clearly a connection between homoserine lactone signaling and biofilm formation in E. coli. This implies that $E$. coli uses the homoserine lactone signaling pathway to monitor at least indole and homoserine lactone compounds (this report) as well as uses the AI-2 signaling pathway $[4,5]$ to control biofilms. Hence, although E. coli does not produce its own homoserine lactone via a signal synthase, it uses its homoserine lactone transcriptional regulator (SdiA) to monitor indole-producing strains as well as to monitor strains like $P$. aeruginosa (produces $N$ butyryl-L-homoserine lactone [32]), P. syringae (produces $N$-hexanoyl-L-homoserine lactone [33]), and $P$. fluorescens (produces $N$-octanoyl- $L$-homoserine lactone [33]). In addition, two groups have found SdiA induces the multidrug efflux pump AcrAB of E. coli $[18,21]$, and AcrAB has been hypothesized to control the efflux of quorum signals [18]. Given that we demonstrated TqsA of E. coli controls the efflux of the quorum signal AI-2 [5], and others demonstrated MexAB-OprM of P. aeruginos a controls the efflux of the quorum signal $\mathrm{N}$-(3-oxododecanoyl)-L-homoserine lactone $[43,44]$, it appears indole via its control of SdiA, may also control the efflux of quorum signals as well as control antibiotic resistance [7].

It needs to be ascertained whether indole itself binds to SdiA which has now been shown to bind four homoserine lactones $[22,23]$. The induction of $s d i A$ upon addition of indole (ascertained through our microarrays), the decrease in sdiA-mediated transcription upon indole addition (shown via the $\beta$-galactosidase reporter of the ftsQ2p promoter), the lack of response in biofilm formation upon addition of homoserine lactones by the sdiA mutant, the lack of change in acid resistance upon indole addition by the sdiA mutant, and the fact that exogenous indole did not reduce the biofilm of the sdiA mutant, all suggest indole may bind SdiA. Furthermore, our results indicate that the extracellular factor first seen by GarcíaLara et al. [31] in an AI-2 minus background, which was shown to regulate the $f t s Q 2 p$ cell division promoter via SdiA and to regulate sdiA, is indole. Significantly, indole and the AHLs have opposing effects on acid resistance and $f t s Q 2 p$ transcription: indole reduced $f t s Q 2 p$ transcription as well as reduced acid resistance but $N$-butyryl- $D L$-homoserine lactone increased $f t s 2 p$ transcription in this study. Furthermore, $N$-decanoyl- $D L$-homoserine lactone is known to increase ftsQ2p transcription [45], and N-hexanoyl- $L$-homoserine lactone enhances acid resistance by inducing gadA more than 120-fold [23]. Hence, these results indicate different roles of indole and AHLs on acidresistance via SdiA. Also, since indole controls biofilm formation through SdiA, these are some of the first results with SdiA showing a phenotypic change in E. coli K12 [46]. Since indole and $N$-butyryl- $D L$-homoserine lactone showed a marginal effect on plasmid-encoded ftsQ2p expression as previously reported $[31,45]$, measurement of $f t s Q 2 p$ expression from its natural position in the chromosome [19] would be required to corroborate our results.

We also propose that the DNA microarray analysis here provides insight into how the bacteria of the gastrointestinal (GI) tract may help to restrict access to pathogens and how it may regulate acid resistance, motility, and biofilm formation of non-pathogenic bacteria. An increase in extracellular indole in the GI tract by non-pathogenic bacteria may repress genes that encode regulators such as gadX (Table 2) and thereby reduce virulence in the duodenum since GadX activates virulence genes there [47]. Also, it appears that non-pathogenic E. coli may turn off acid resistance genes (gad and hde operons, Table 2) in the presence of indole in the weak basic gut flora since they are no longer needed, so indole serves to regulate acid resistance. Also, this increase in indole may serve to regulate motility in a complex manner (Table 2) and allow cells to form a biofilm. We speculate that the extracellular levels of indole increase only after the non-pathogenic biofilms have reached a certain critical thickness so that indole may decrease motility in the colonizing pathogenic bacteria and allow them to be more effectively removed from the gastrointestinal tract (indole is a negative chemoattractant for $E$. coli O157:H7, unpublished results). The pathogen E. coli O157:H7 may use indole as a signal since SdiA represses expression of the virulence factors EspD and intimin [20]. In addition, indole from bacteria is absorbed into body [48] so it easy to imagine that cells of the gastrointestinal tract may also manipulate indole levels to control bacteria.

Since we found extracellular concentration of indole decreases for K-12 cultures from $450 \pm 70 \mu \mathrm{M}$ to $15 \pm 6 \mu \mathrm{M}$ upon the addition of glucose to LB medium due to catabolite repression of tnaA [25], some of the results here and in our earlier reports $[5,14,16,49]$ may need to be interpreted in light of changes in indole concentrations. For example, out of 93 isogenic knockout mutants identified with temporal biofilm microarrays, 70 mutants 
showed a more distinctive change in biofilm formation relative to the wild-type strain in LB glu medium compared to LB medium [49]. Here, the K-12 trpE, tnaC, trpL, gadA, and hdeA mutants had more significant biofilm changes in LB glu (Fig. 4, where indole concentrations are minimal) compared to LB.

It is becoming clear that prokaryotes and eucaryotes signal not only themselves but also one another; for example, there appears to be crosstalk between E. coli O157:H7 and cells of the gastrointestinal tract through the hormones epinephrine and norepinephrine (catecholamines) [50]. Other hormones are also present in the gastrointestinal tract including melatonin [51] and serotonin [52]; both are neural hormones which maintain homeostasis and both reduce chlamydial infection [53]. In addition, plants use indole 3-acetic acid as their main hormone (for cell growth, division, tissue differentiation, and response to light and gravity), and bacteria interrupt this eucaryotic signaling by using indole-3-acetic acid as a source of carbon, nitrogen, and energy [54]. All five hormones, such as indole, indole-3-acetic acid, serotonin, melatonin, and epinephrine, have indole-like chemical structures (Fig. 8); hence, although it is highly speculative, it is intriguing to ponder whether indole was incorporated into the metabolism of eucaryotic hosts (plants and animals) and is the archetypal hormone.

\section{Conclusion}

Indole is shown to clearly inhibit $E$. coli biofilm formation and DNA microarrays were used to determine that the mechanism of this inhibition is through SdiA. Indole is an interspecies biofilm signal as it is also shown here that it regulates pseudomonad biofilms, and it is shown that this signal can be manipulated by non-specific oxygenases in a dual-species biofilm to control the population of each bacterium. For the first time, it is also shown that both $E$. coli and pseudomonads respond to biofilm signals they do not synthesize.

\section{Methods}

\section{Bacterial strains, materials and growth}

The strains and plasmids used are listed in Table 3. LB [55] was used to pre-culture all the E. coli cells. LB glu was used for the single species biofilm experiments whereas LB was used for the dual species. To determine indole toxicity, $E$. coli $\mathrm{K}-12$ was grown with 0 to $500 \mu \mathrm{M}$ indole with dimethylformamide (DMF) added at $0.1 \%(\mathrm{v} / \mathrm{v})$ to all samples. The $\mathrm{N}$-acylhomoserine lactones were purchased from Aldrich (Allentown, PA).

\section{Crystal violet biofilm assay}

This assay was adapted [29]; E. coli was grown in polystyrene 96 well plates at $37^{\circ} \mathrm{C}$ for one day without shaking in LB glu medium except for the homoserine lactone experiment which was conducted at $30^{\circ} \mathrm{C}$ in $\mathrm{LB}$ medium. $P$. aeruginosa and $P$. fluorescens were cultured in LB at $30^{\circ} \mathrm{C}$. Each data point was averaged from twelve replicate wells (six wells from two independent cultures) and the standard deviations were calculated. Plates were processed after 24 hours. The experiments were performed two or four times using independent cultures.

\section{Single-species biofilms in flow cells}

The inocula and biofilm growth medium was LB glu supplemented with $300 \mu \mathrm{g}$ erythromycin $\mathrm{ml}^{-1}$ to maintain pCM18 [56] to retain the constitutive GFP vector for visualizing the biofilm; $50 \mu \mathrm{g}$ kanamycin $\mathrm{ml}^{-1}$ was used for the inocula of the trpE and tnaC mutants. The biofilm was formed at $37^{\circ} \mathrm{C}$ in a continuous flow cell and visualized with confocal microscopy as described previously [30]. The inocula were diluted to a turbidity of 0.05 at $600 \mathrm{~nm}$ and used to seed the flow cell for $2 \mathrm{~h}$ at $10 \mathrm{ml} \mathrm{h}^{-1}$ before fresh LB glu erythromycin medium was added at the same flow rate. To study the effect of indole, indole in DMF was added at $500 \mu \mathrm{M}$ upon inoculation and in the continuous feed; DMF was added as the negative control to the noindole flow cell. The initial inoculum was 1.9 to $7.7 \times 10^{7}$ cells $\mathrm{ml}^{-1}$.

\section{Dual-species biofilms in flow cells}

E. coli K-12 ATCC25404 harboring pGEM-T RFP, derived from pGEM-T (Promega, Madison, WI) and containing the constitutively expressed RFP, was cultured with either $P$. fluorescens 2-79TOM (expresses constitutively toluene $o$ monooxygenase to convert indole to isoindigo [28]) or $P$. fluorescens $2-79$ as the negative control. TOM activity of $P$. fluorescens 2-79TOM was determined to be $0.37 \mathrm{nmol} /$ min mg protein using a naphthalene to naphthol assay based on HPLC [57]. LB medium with $100 \mu \mathrm{g}$ ampicillin $\mathrm{ml}^{-1}$ to maintain plasmid pGEM-T RFP was used to form biofilms at $32^{\circ} \mathrm{C}$ in the continuous flow cell (the two $P$. fluorescens strains were naturally-resistant to $100 \mu \mathrm{g}$ ampicillin $\mathrm{ml}^{-1}$ ). RFP allowed visualization of the E. coli bio-

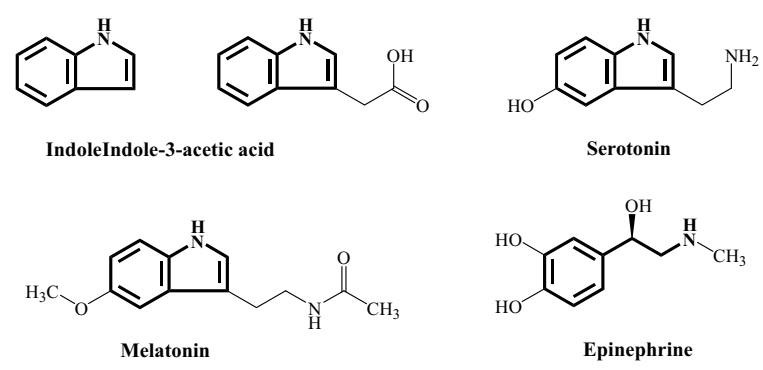

Figure 8

Indole, melatonin, serotonin, epinephrine, and indole-3-acetic acid. Indole motifs are in bold. 
film by excitation at $546 \mathrm{~nm}$ and emission at $590 \mathrm{~nm}$. The experiment was performed in duplicate.

In a second dual-species biofilm system, both pseudomonads contained RFP via the broad-host-range plasmid pHKT3 [58] and E. coli K-12 XL1-Blue was used with GFP from pCM18 [56]; in this way, both bacteria were tagged with a flourophore. TOM was active in $P$. fluorescens 2-79TOM/pHKT3 (RFP) $(0.24 \mathrm{nmol} / \mathrm{min} \mathrm{mg}$ protein). Also, the addition of TOM to P. fluorescens/pHKT3 did not reduce its growth rate. LB medium supplemented with $20 \mu \mathrm{g}$ tetracycline $\mathrm{ml}^{-1}$ (to maintain plasmid pHKT3 and to select for the E. coli host) was used to form biofilms at $32{ }^{\circ} \mathrm{C}$ in the continuous flow cell (pCM18 was stable in E. coli without antibiotics but not in $P$. fluorescens). RFP allowed visualization of the $P$. fluorescens biofilm by exciting with a HeNe laser at $543 \mathrm{~nm}$ (emission 590 - $680 \mathrm{~nm}$ ) and GFP allowed visualization of the E. coli biofilm by exciting with a Ar laser at $488 \mathrm{~nm}$ (emission 510 - 530 $\mathrm{nm}$ ) using a TCS SP5 scanning confocal laser microscope with a 63x HCX PL FLUOTAR L dry objective with correction collar and numerical aperture of 0.7 (Leica Microsystems, Mannheim, Germany). Overnight cultures of both bacteria were diluted to a turbidity of 0.05 at $600 \mathrm{~nm}$ and used to inoculate the flow chamber for two hours at $10 \mathrm{ml}$ $\mathrm{h}^{-1}$ (roughly $2.6 \times 10^{7}$ cells ml $^{-1}$ ). Fresh LB medium with $20 \mu \mathrm{g}$ tetracycline $\mathrm{ml}^{-1}$ was then introduced at the same flow rate and circulated for 7 days.

\section{Flow cell image analysis}

Color confocal flow cell images were converted to gray scale [30], and biomass, substratum coverage, surface roughness, and mean thickness were determined using COMSTAT image-processing software [26] as described previously [30]. At each time point, from five to nine different positions were chosen for microscope analysis and 25 images were processed for each point. Values are means of data from the different positions at the same time point, and standard deviations were calculated based on these mean values for each position. Simulated threedimensional images were obtained using IMARIS (BITplane, Zurich, Switzerland). Twenty-five pictures were processed for each three-dimensional image.

\section{Motility assay}

LB overnight cultures were used to assay motility in plates containing $1 \%(\mathrm{w} / \mathrm{v})$ tryptone and $0.25 \%(\mathrm{w} / \mathrm{v}) \mathrm{NaCl}$ and $0.3 \%(\mathrm{w} / \mathrm{v})$ agar [59]. The motility halos were measured at $8 \mathrm{~h}$. When the effect of indole on motility was tested, indole $(500 \mu \mathrm{M})$ dissolved in DMF was added to the motility agar. DMF $(0.1 \%, \mathrm{v} / \mathrm{v})$ was added as the negative control. Each experiment was performed two or four times using two independent cultures with each culture evaluated in triplicate. Also, it was confirmed that the motility with $0.1 \%(\mathrm{v} / \mathrm{v})$ DMF was nearly identical to motility without DMF.

\section{Biofilm total RNA isolation for DNA microarrays}

For all 3 sets of microarray experiments, $10 \mathrm{~g}$ glass wool (Corning Glass Works, Corning, N.Y.) were used to form

Table 3: Strains and plasmids used. Amp ${ }^{R}, \operatorname{Erm}^{R}$, $\operatorname{Tet}^{R}$, and $\mathrm{Km}^{\mathrm{R}}$ are ampicillin, erythromycin, tetracycline and kanamycin resistance, respectively.

\begin{tabular}{|c|c|c|}
\hline Strains and Plasmids & Genotype & Source \\
\hline \multicolumn{3}{|l|}{ Strains } \\
\hline E. coli K-12 BW25II3 & lacla rrnB ${ }_{T / 4} \Delta$ lac $Z_{\mathrm{WJ16}}$ hsdR5I4 $\Delta a r a B A-D_{\mathrm{AH} 33} \Delta r h a B A D_{\mathrm{LD} 78}$ & [67] \\
\hline E. coli K-I2 BW25I I 3 trpE & $\mathrm{K}-12 \Delta \operatorname{trp} E:: \mathrm{Km}^{\mathrm{R}}$, defective in anthranilate synthase component I & [67] \\
\hline E. coli K-12 BW25II3 $\Delta$ tnaC & $\mathrm{K}-12 \Delta$ tnaC:: $\mathrm{Km}^{\mathrm{R}}$, defective in the tryptophanase leader peptide & {$[67]$} \\
\hline E. coli K-I2 BW25II3 $\Delta$ trpL & $\mathrm{K}-12 \Delta \operatorname{trp} \mathrm{L}:: \mathrm{Km}^{\mathrm{R}}$, defective in the trp operon leader peptide & {$[67]$} \\
\hline E. coli K-12 BW25II $3 \Delta$ tnaA & $\mathrm{K}-12 \Delta$ tnaA::: $\mathrm{Km}^{\mathrm{R}}$, defective in tryptophan deaminase & {$[67]$} \\
\hline E. coli K-12 BW25II3 $\Delta$ gadA & $\mathrm{K}-12 \Delta \operatorname{gadA}:: \mathrm{Km}^{\mathrm{R}}$, defective in the acid resistance gene glutamate decarboxylase $\mathrm{A}$ & {$[67]$} \\
\hline E. coli K-I2 BW25II3 $\Delta$ hdeA & $\mathrm{K}-12 \Delta h d e A:: \mathrm{Km}^{\mathrm{R}}$, defective in acid resistance & [67] \\
\hline E. coli K-12 BW25II3 $\Delta$ sdiA & $\mathrm{K}-12 \Delta s d i A:: \mathrm{Km}^{\mathrm{R}}$, defective in sensing autoinducer-I & {$[67]$} \\
\hline E. coli K-12 ATCC 25404 & wild-type & ATCC \\
\hline E. coli K-I2 ATCC25404/PGEM-T RFP & $A m P^{R}, \mathrm{RFP}^{+}$ & this work \\
\hline E. coli K-I2 XLI-Blue/pCMI8 & $\begin{array}{l}\text { recAl, lac, endAI, gyrA96, thi, hsdRI7, supE44, relAI/F' proAB', laclq, lacZ } \Delta M \mid 3 \text {, Tn } 10 \mathrm{Tet}^{\mathrm{R}} \text {, } \\
\text { Erm }^{\mathrm{R}}, \mathrm{GFP}^{+}\end{array}$ & this work \\
\hline E. coli UT48I/pCX39 & Llac-pro met pro zzz::Tn 10 thy supD $r_{K^{-}}-m_{K^{-}}-/ f t s Q 2 p:: I a c Z, A m p^{R}$ & {$[31]$} \\
\hline E. coli WX2/pCX39 & 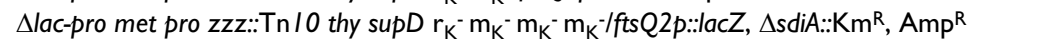 & {$[31]$} \\
\hline E. coli JMI09 & recAl supE44 endAI hsdRI 7 gyrA96 relAI thi $\Delta\left(\right.$ lac-proAB) $\mathrm{F}^{\prime}$ [traD36 proAB+laclalacZ $\left.\Delta M \mid 5\right]$ & [68] \\
\hline E. coli TGI & supE hsd $\Delta 5$ thi $\Delta$ (lac-proAB) $\mathrm{F}^{\prime}[\operatorname{traD} 36$ proAB+lacla lacZ $\Delta M \mid 5]$ & [55] \\
\hline P. aeruginosa PAOI & wild-type & T. McDermott \\
\hline P. fluorescens $2-79$ & wild-type (NRRL B-I5।32) TOM- & [28] \\
\hline P. fluorescens 2-79TOM & P. fluorescens $2-79 \mathrm{TOM}^{+}, \mathrm{Km}^{\mathrm{R}}$ & [28] \\
\hline P. fluorescens 2-79TOM/pHKT3 & $\mathrm{TOM}^{+}, \mathrm{Km}^{\mathrm{R}}, \mathrm{Tet}^{\mathrm{R}} \mathrm{RFP}^{+}$ & this work \\
\hline P. fluorescens 2-79/pHKT3 & $\mathrm{TOM}^{-}, \mathrm{Tet}^{\mathrm{R}} \mathrm{RFP}^{+}$ & this work \\
\hline
\end{tabular}


biofilms [11] in $250 \mathrm{ml}$ in $1 \mathrm{~L}$ Erlenmeyer shake flasks which were inoculated with overnight cultures diluted that were 1:100. For K-12 yceP with indole, $600 \mu \mathrm{M}$ indole in $150 \mu \mathrm{L} \mathrm{DMF}$ or $150 \mu \mathrm{L}$ DMF alone were added to cells grown in LB glu. For K-12 tnaA vs. K-12 wild-type, cells were grown in LB, and for K-12 $\operatorname{trpE}$ vs. K-12 wild-type, cells were grown in LB glu. The cells were shaken at 250 $\mathrm{rpm}$ and $37^{\circ} \mathrm{C}$ for 24 hours to form biofilms on the glass wool, and RNA was isolated from the biofilm as described previously [11].

\section{DNA microarrays}

The E. coli Genechip antisense genome array (Affymetrix, $\mathrm{P} / \mathrm{N}$ 900381) which contains probe sets for all 4290 open reading frames (ORF), rRNA, tRNA, and 1350 intergenic regions was used to study the differential gene expression profile for indole addition and for the tnaA and trpE mutants compared to the isogenic wild-type K-12 in a mature biofilm as described previously [4]. Hybridization was performed for $16 \mathrm{~h}$ and the total cell intensity was scaled automatically in the software to an average value of 500. The data were inspected for quality and analyzed according to the procedures described in Data Analysis Fundamentals which includes using premixed polyadenylated transcripts of the B. subtilis genes (lys, phe, thr, dap) at different concentrations. Also, as expected, there was insignificant tnaA and trpE mRNA signals in the biofilm of the tnaA and $\operatorname{trp} E$ mutants, and the completely-deleted $E$. coli K-12 BW25113 genes araA and rhaA showed insignificant mRNA levels. Genes were identified as differentially expressed if the expression ratio was greater than 2 and the change $\mathrm{p}$-value is less than 0.05 since the standard deviations were 1.0 and 1.2 from duplicate experiments for indole, 1.4 for tnaA, and 1.2 for trpE. The gene functions were obtained from the National Center for Biotechnology Information database [60] and from the EcoCyc database $[61,62]$. The expression data for the biofilm samples have been deposited in the NCBI Gene Expression Omnibus [63] and are accessible through GEO Series accession number GSE4562 [64,65].

\section{Indole and $\beta$-galactosidase assays}

Extracellular and intracellular indole concentrations from cells in LB medium were measured spectrophotometrically in duplicate as described previously [14] by modifying the protocol of Kawamura-Sato et al. [66]. Also, the spectrophotometric indole assay was corroborated with reverse-phase HPLC using a $100 \times 4.6 \mathrm{~mm}$ Chromolith Performance RP-18e column (Merck KGaA, Darmstadt, Germany) and gradient elution with $\mathrm{H}_{2} \mathrm{O}-0.1 \%$ (v/v) formic acid and acetonitrile as the mobile phases at a flow rate of $1 \mathrm{ml} \mathrm{min}^{-1}$ (65:35 for 0-5 $\mathrm{min}, 35: 65$ for 5-12 min, and $65: 35$ at $12 \mathrm{~min}$ ). Under these conditions, the retention time for indole was $5.9 \mathrm{~min}$, and the absorbance maximum was $271 \mathrm{~nm}$.
E. coli UT481 harboring pCX39 (ftsQ2p::lacZ) and E. coli WX2 (sdiA-) harboring pCX39 (ftsQ2p::lacZ) [31] was grown at $30^{\circ} \mathrm{C}$ with $100 \mu \mathrm{g}$ ampicillin $\mathrm{ml}^{-1}$ from diluted overnight cultures to a turbidity of 1.0 or 2.0 at $600 \mathrm{~nm}$. The $\beta$-galactosidase activities were calculated based on a protein concentration of $0.24 \mathrm{mg}$ protein $\mathrm{ml}^{-1} \mathrm{O} \mathrm{D}_{600}{ }^{-1}$ as reported previously [49].

\section{Acid resistance assay}

This assay was adapted [35]. Overnight cultures grown for $19 \mathrm{~h}$ in LB were re-grown to mid-log phase in LB (turbidity at $600 \mathrm{~nm}$ of 1), and the culture was diluted 40 -fold into phosphate-buffered saline ( $\mathrm{pH} 7.2)$ or $\mathrm{LB}(\mathrm{pH} 2.5)$ at $37^{\circ} \mathrm{C}$. E. coli in LB (pH 2.5) was incubated at $37^{\circ} \mathrm{C}$ for 1 $\mathrm{h}$ without shaking. Indole was also added during the acid challenge to determine its effect. The percentage of cells surviving the acid treatment was calculated as the number of colony forming units (CFU) $\mathrm{ml}^{-1}$ remaining after acid treatment divided by the initial CFU $\mathrm{ml}^{-1}$ at time zero.

\section{Authors' contributions}

JL designed research, performed experiments, analyzed the data, and helped draft the manuscript. AJ participated in the design of the study. TKW conceived the study, designed experiments, analyzed data, and wrote much of the manuscript. All authors read and approved the final manuscript.

\section{Acknowledgements}

This research was supported by the NIH (EB003872-0IAI) and ARO (W9I INF-06-I-0408). We thank Prof. R. Jayaraman (Madurai Kamaraj University) and Dr. Rodolfo García Contreras (Texas A\&M University) for their comments and are grateful for the gift of PHKT3 by Prof. Howard Ceri (University of Calgary), the gift of $E$. coli UT48I/PCX39 by Prof. Lawrence Rothfield (University of Connecticut), and the gift of mutants from the $E$. coli Keio collection by the National of Institute of Genetics, Japan.

\section{References}

I. Hammer BK, Bassler BL: Quorum sensing controls biofilm formation in Vibrio cholerae. Mol Microbiol 2003, 50(1): 10I-104.

2. Henke JM, Bassler BL: Three parallel quorum-sensing systems regulate gene expression in Vibrio harveyi. J Bacteriol 2004, I86(20):6902-69|4.

3. Davies DG, Parsek MR, Pearson JP, Iglewski BH, Costerton JW, Greenberg EP: The Involvement of Cell-to-Cell Signals in the Development of a Bacterial Biofilm. Science 1998, 280:295-298.

4. González Barrios AF, Zuo R, Y. Hashimoto, Yang L, Bentley WE, Wood TK: Autoinducer 2 Controls Biofilm Formation in Escherichia coli Through a Novel Motility Quorum Sensing Regulator (MqsR, B3022). J Bacteriol 2006, I 88:305-3I6.

5. Herzberg M, Kaye IK, Peti W, Wood TK: YdgG (TqsA) Controls Biofilm Formation in Escherichia coli K-12 by Enhancing Autoinducer 2 Transport. J Bacteriol 2006, 1 88:587-598.

6. Wang D, Ding X, Rather PN: Indole Can Act as an Extracellular Signal in Escherichia coli. J Bacteriol 2001, 183:42 10-4216.

7. Hirakawa H, Inazumi Y, Masaki T, Hirata T, Yamaguchi A: Indole induces the expression of multidrug exporter genes in Escherichia coli. Molecular Microbiology 2005, 55: I I I3-I I 26.

8. Anyanful A, Dolan-Livengood JM, Lewis T, Sheth S, DeZalia MN, Sherman MA, Kalman LV, Benian GM, Kalman D: Paralysis and killing of Caenorhabditis elegans enteropathogenic Escherichia coli requires the bacterial tryptophanase gene. Molecular Microbiology 2005, 57:988-1007. 
9. Chant EL, Summers DK: Indole signalling contributes to the stable maintenance of Escherichia coli multicopy plasmids. Mol Microbiol 2006, 63(I):35-43.

10. Ren D, Bedzyk LA, Ye RW, Thomas SM, Wood TK: Stationary Phase Quorum-Sensing Signals Affect Autoinducer-2 and Gene Expression in Escherichia coli. Appl Environ Microbiol 2004 , 70(4):2038-2043.

II. Ren D, Bedzyk LA, Thomas SM, Ye RW, Wood TK: Gene Expression in Escherichia coli Biofilms. Appl Microbiol Biotechnol 2004 64(4):515-524.

12. Beloin C, Ghigo JM: Finding gene-expression patterns in bacterial biofilms. Trends Microbiol 2005, I3:16-19.

13. Lazazzera BA: Lessons from DNA microarray analysis: the gene expression profile of biofilms. Curr Opin Microbiol 2005, 8:222-227.

14. Domka J, Lee J, Wood TK: YliH (BssR) and YceP (BssS) Regulate Escherichia coli K-I 2 Biofilm Formation By Influencing Cell Signaling. Appl Environ Microbiol 2006, 72(4):2449-2459.

15. Di Martino P, Fursy R, Bret L, Sundararaju B, Phillips RS: Indole can act as an extracellular signal to regulate biofilm formation of Escherichia coli and other indole-producing bacteria. Can Microbiol 2003, 49:443-449.

16. González Barrios AF, Zuo R, Ren D, Wood TK: Hha, Ybaj, adn OmpA Regulate Escherichia coli KI 2 Biofilm Formation and Conjugation Plasmids Abolish Motility. Biotechnol Bioeng 2006 , 93:188-200.

17. Lindsay A, Ahmer BMM: Effect of sdiA on biosensors of $\mathbf{N}$-acylhomoserine lactones. J Bacteriol 2005, I 87( I 4):5054-5058.

18. Rahmati S, Yang S, Davidson AL, Zechiedrich EL: Control of the AcrAB multidrug efflux pump by quorum-sensing regulator SdiA. Mol Microbiol 2002, 43:677-685

19. Michael B, Smith JN, Swift S, Heffron F, Ahmer BM: SdiA of Salmonella enterica is a LuxR homolog that detects mixed microbial communities. I Bacteriol 200 I, I 83( I9):5733-5742.

20. Kanamaru K, Kanamaru K, Tasuno I, Tobe T, Sasakawa C: SdiA, an Escherichia coli homologue of quorum-sensing regulators, controls the expression of virulence factors in enterohaemorrhagic Escherichia coli Ol57:H7. Mol Microbiol 2000, 38:805-8I6.

21. Wei Y, Lee JM, Smulski DR, LaRossa RA: Global Impact of sdiA Amplification Revealed by Comprehensive Gene Expression Profiling of Escherichia coli. J Bacteriol 200I, I 83:2265-2272.

22. Yao Y, Martinez-Yamout MA, Dickerson TJ, Brogan AP, Wright PE, Dyson HJ: Structure of the Escherichia coli quorum sensing protein SdiA: Activation of the folding switch by acyl homoserine lactones. J Mol Biol 2006, 355:262-273.

23. van Houdt R, Aertsen A, Moons P, Vanoirbeek K, Michiels CW: NAcyl-L-homoserine lactone signal interception by Escherichia coli. FEMS Microbiology Letters 2006, 256:83-89.

24. Neidhardt FC: Escherichia coli and Salmonella : Cellular and molecular biology. Volume 2. 2nd edition. Washington, D.C. , ASM Press; 1996:2822.

25. Botsford JL, deMoss RD: Catobolite repression of tryptophanase in Escherichia coli. I Bacteriol I971, I 05:303-312.

26. Heydorn A, Nielsen AT, Hentzer M, Sternberg C, Givskov M, Ersbøll BK, Molin S: Quantification of Biofilm Structures by the Nove Computer Program COMSTAT. Microbiology 2000, I 46:2395-2407.

27. Rui L, Reardon KF, Wood TK: Protein engineering of toluene ortho-monooxygenase of Burkholderia cepacia G4 for regiospecific hydroxylation of indole to form various indigoid compounds. Appl Microbiol Biotechnol 2005, 66(4):422-429.

28. Yee DC, Maynard JA, Wood TK: Rhizoremediation of trichloroethylene by a recombinant, root-colonizing Pseudomonas fluorescens strain expressing toluene ortho-monooxygenase constitutively. Appl Environ Microbiol 1998, 64(I): I I2-I I8.

29. Pratt LA, Kolter R: Genetic analysis of Escherichia coli biofilm formation: roles of flagella, motility, chemotaxis and type I pili. Mol Microbiol 1998, 30(2):285-293.

30. Wood TK, González Barrios AF, Herzberg M, Lee J: Motility influences biofilm architecture in Escherichia coli. Appl Microbiol Biotechnol 2006, 72(2):36I-367.

31. Garcia-Lara J, Shang LH, Rothfield LI: An extracellular factor regulates expression of sdiA, a transcriptional activator of cell division genes in Escherichia coli. J Bacteriol 1996 I 78( I 0):2742-2748
32. Pesci EC, Milbank JBJ, Pearson JP, McKnight S, Kende AS, Greenberg $\mathrm{EP}$, Iglewski $\mathrm{BH}$ : Quinolone signaling in the cell-to-cell communication system of Pseudomonas aeruginosa. Proc Natl Acad Sci 1999, 96: II 229-1|234

33. Elasri M, Delorme S, Lemanceau P, Stewart G, Laue B, Glickmann E, Oger PM, Dessaux Y: Acyl-homoserine lactone production is more common among plant-associated Pseudomonas spp. than among soilborne Pseudomonas spp. Appl Environ Microbiol 200I, 67(3): II98-1209.

34. Ma Z, Gong S, Richard H, Tucker DL, Conway T, Foster JW: GadE (YhiE) activates glutamate decarboxylase-dependent acid resistance in Escherichia coli K-12. Mol Microbiol 2003 49:1309-1320.

35. Masuda N, Church GM: Regulatory network of acid resistance genes in Eshcerichia coli. Mol Microbiol 2003, 48:699-7I2.

36. Yanofsky C, Horn V, Gollnick P: Physiological Studies of Tryptophan Transport and Tryptophanase Operon Induction in Escherichia coli. | Bacteriol |99|, I73:6009-6017.

37. Webb JS, Lau M, Kjelleberg S: Bacteriophage and phenotypic variation in Pseudomonas aeruginosa biofilm development. Bacteriol 2004, I 86:8066-8073.

38. Xavier KB, Bassler BL: Interference with Al-2-Mediated Bacterial Cell-Cell Communication. Nature 2005, 437:750-753.

39. Zhang LH, Dong YH: Quorum sensing and signal interference: diverse implications. Mol Microbiol 2004, 53: I563-I57|.

40. Ren D, Bedzyk LA, Thomas SM, Ye RW, Wood TK: Differential Gene Expression Shows Natural Brominated Furanones Interfere with the Autoinducer-2 Bacterial Signaling System of Escherichia coli. Biotechnol Bioeng 2004, 88(5):630-642.

4I. Yang F, Wang LH, Wang J, Dong YH, Hu JY, Zhang LH: Quorum quenching enzyme activity is widely conserved in the sera of mammalian species. FEBS Lett 2005, 579:37I3-37I7.

42. Fishman A, Tao Y, Rui L, Wood TK: Controlling the regiospecific oxidation of aromatics via active site engineering of toluene para-monooxygenase of Ralstonia pickettii PKOI. J Biol Chem 2005, 280:506-5i4

43. Evans K, Passador L, Srikumar R, Tsang E, Nezezon J, Poole K: Influence of the MexAB-OprM multidrug efflux system on quorum sensing in Pseudomonas aeruginosa. J Bacteriol 1998 , I 80(20):5443-5447.

44. Pearson JP, Van Delden C, Iglewski BH: Active efflux and diffusion are involved in transport of Pseudomonas aeruginosa cell-tocell signals. J Bacteriol 1999, I 8 I (4): | 203- I 2 I0.

45. Sitnikov DM, Schineller JB, Baldwin TO: Control of cell division in Escherichia coli: regulation of transcription of fts $Q A$ involves both rpoS and SdiA-mediated autoinduction. Proc Natl Acad Sci U S A 1996, 93(I):336-34I

46. Walters M, Sperandio V: Quorum sensing in Escherichia coli and Salmonella. Int J Med Microbiol 2006, 296: I 25-I3I.

47. Moreira CG, Palmer K, Whiteley M, Sircili MP, Trabulsi LR, Castro AFP, Sperandio V: Bundle-Forming Pili and EspA are involved in biofilm formation by enteropathogenic Escherichia coli. J Bacteriol 2006, | 88:3952-396I.

48. Gillam EMJ, Notley LM, Cai H, De Voss JJ, Guengerich FP: Oxidation of Indole by Cytochrome P450 Enzymes. Biochemistry 2000, 39: | 3817-13824.

49. Domka J, Lee J, Bansal T, Wood TK: Temporal Gene-Expression in Escherichia coli K-I2 Biofilms. Environ Microbiol 2007, 9:332-346.

50. Kaper JB, Sperandio V: Bacterial Cell-to-Cell Signaling in the Gastrointestinal Tract. Infect Immun 2005, 73(6):3197-3209.

51. Lee PPN, Pang SF: Melatonin and its receptors in the gastrointestinal tract. Biol Signals 1993, 2:181-193.

52. Meyer T, Brinck U: Differential Distribution of Serotonin and Tryptophan Hydroxylase in the Human Gastrointestinal Tract. Digestion 1999, 60(I):63-68

53. Rahman MA, Azuma Y, Fukunaga H, Murakami T, Sugi K, Fukushi H, Miura K, Suzuki H, Shirai M: Serotonin and melatonin, neurohormones for homeostasis, as novel inhibitors of infections by the intracellular parasite chlamydia. I Antimicrob Chemother 2005, 56:86I-868.

54. Leveau JHJ, Lindow SE: Utilization of the plant hormone indole3-acetic acid for growth by Pseudomonas putida strain I 290. Appl Environ Microbiol 2005, 7 I(5):2365-237I. 
55. Sambrook J, Fritsch EF, Maniatis T: Molecular Cloning, A Laboratory Manual. 2nd edition. Cold Spring Harbor, NY, Cold Spring Harbor Laboratory Press; 1989.

56. Hansen MC, Palmer RJ Jr., Udsen C, White DC, Molin S: Assessment of GFP fluorescence in cells of Streptococcus gordonii under conditions of low $\mathrm{pH}$ and low oxygen concentration. Microbiology 200I, I47(Pt 5):|383-I39|.

57. Tao Y, Bentley WE, Wood TK: Phenol and 2-naphthol production by toluene 4-monooxygenases using an aqueous/dioctyl phthalate system. Appl Microbiol Biotechnol 2005, 68(5):6I4-62I.

58. Tomlin KL, Clark SRD, Ceri H: Green and red fluorescent protein vectors for use in biofilm studies of the intrinsically resistant Burkholderia cepacia complex. J Microbiol Methods 2004, 57:95-106.

59. Sperandio V, Torres AG, Kaper JB: Quorum Sensing Escherichia coli Regulators B and C (QseBC): a Novel Two-component Regulatory System Involved in the Regulation of Flagella and Motility by Quorum Sensing in E. coli. Mol Microbiol 2002, 43:809-821.

60. National Center for Biotechnology Information database [http://www.ncbi.nlm.nih.gov/]

6I. Keseler IM CVJ Gama-Castro S, Ingraham J, Paley S, Paulsen IT, Peralta-Gil M, Karp PD: EcoCyc: a comprehensive database resource for Escherichia coli. Nuc Acid Res 2005, 33(Database Issue):D334-D337.

62. EcoCyc database [http://biocyc.org/ECOLI/]

63. NCBI Gene Expression Omnibus [http://www.ncbi.nlm.nih.gov/ geo/]

64. Barrett T, Suzek TO, Troup DB, Wilhite SE, Ngau WC, Ledoux P, Rudnev D, Lash AE, Fujibuchi W, Edgar R: NCBI GEO: Mining Millions of Expression Profiles-Database and Tools. Nucleic Acids Res 2005, 33(Database Issue):D562-D566.

65. Edgar R, Domrachev M, Lash AE: Gene Expression Omnibus: NCBI Gene Expression and Hybridization Array Data Repository. Nucleic Acids Res 2002, 30(I):207-2I0.

66. Kawamura-Sato K, Shibayama K, Horii T, limuma Y, Arakawa Y, Ohta M: Role of multiple efflux pumps in Escherichia coli in indole expulsion. FEMS Microbiology Lett 1999, 179:345-352.

67. Baba T, Ara T, Hasegawa M, Takai Y, Okumura Y, Baba M, Datsenko KA, Tomita M, Wanner BL, Mori H: Construction of Escherichia coli K-I2 in-frame, single-gene knockout mutants: the Keio collection. Mol Syst Biol 2006, 2(2006.0008):EI-EI I.

68. Yanisch-Perron C, Vieira J, Messing J: Improved MI3 phage cloning vectors and host strains: nucleotide sequences of the MI3mpI 8 and pUCI 9 vectors. Gene 1985, 33(I):103-II9.
Publish with BioMed Central and every scientist can read your work free of charge

"BioMed Central will be the most significant development for disseminating the results of biomedical research in our lifetime. "

Sir Paul Nurse, Cancer Research UK

Your research papers will be:

- available free of charge to the entire biomedical community

- peer reviewed and published immediately upon acceptance

- cited in PubMed and archived on PubMed Central

- yours - you keep the copyright
BioMedcentral 